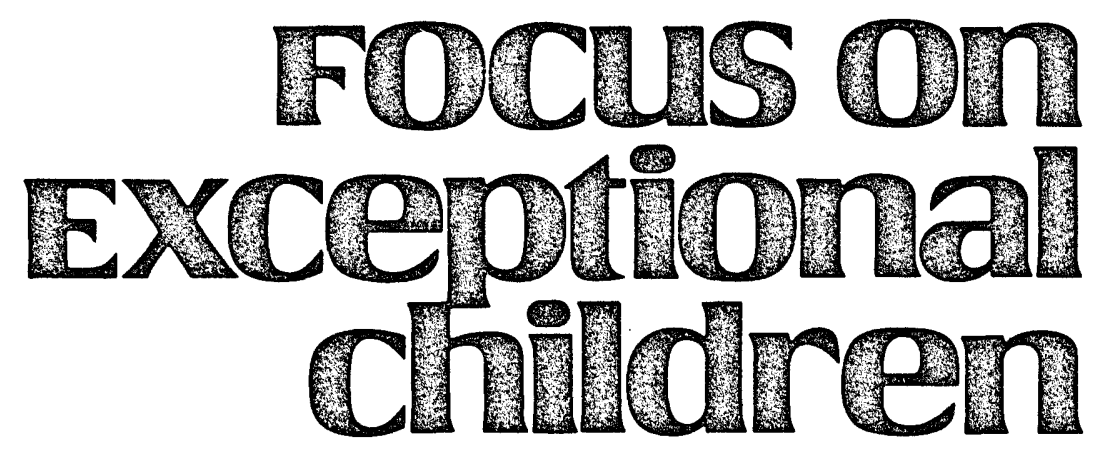

\title{
Disciplinary Removal of Special Education Students
}

David B. Center and Sandra McKittrick

Much debate and discussion presently surround the issue of removing handicapped students from their school programs for disciplinary reasons. This removal usually takes one of three forms. The most serious form of removal from school is expulsion, generally defined as disciplinary removal from school for more than 10 days. Suspension, another form of disciplinary removal, by definition lasts no more than 10 days. A third form of disciplinary removal is in-school suspension, which removes a student from regular and special education classes but not from school. This article discusses each of these procedures and some of the legal rulings associated with them. We also offer some detailed suggestions concerning the use of in-school suspension.

\section{EXPULSION AND SUSPENSION}

The U.S. Supreme Court ruled in Wood v. Strickland that students do not have a constitutional right, per se, to education; education was, however, interpreted as qualifying as property and liberty rights. Therefore, a student cannot be deprived of education without due process of law. In Goss v. Lopez, the Supreme Court set forth due process rights that apply to all students prior to removal from school. The court said that the student was entitled to:

—some kind of notice;

- some kind of hearing;

-know what he or she is accused of and the basis for the accusation;

-an opportunity to tell his or her side.

Goss v. Lopez also limits a suspension to no more than 10 days. Presumably, after that point, the action may be considered as an expulsion-which is another issue altogether, because it represents a cessation rather than a suspension of services.

See p. Il for another article, "Effective Teaching for Mildly Handicapped Learners."
Dr. Center is Associate Professor of Special Education (Behavioral Disorders), Georgia State University. Dr. McKittrick is a Behavioral Disorders Consultant, Georgia State Department of Education.

(c) Love Publishing Company, 1987. 
In these two cases the Supreme Court has established a legal position on the expulsion and suspension of students from school that applies to all students. How does this position and federal law impact on the expulsion and suspension of handicapped children? In $S-1 v$. Turlington a state court ruling bearing on the issue of expulsion of handicapped students was affirmed by a U.S. Court of Appeals. In this decision the court affirmed that expulsion of a handicapped child is a change in educational placement and thereby invokes the procedural safeguards of the Education for All Handicapped Children Act of 1975.

The court did not rule, however, that a handicapped child cannot be expelled. The court established the rule that, before an expulsion can take place, a group of professionals must determine that the student's misbehavior is not directly related to the handicapping condition. The court also struck down the school system's argument that the student would have to be ruled "seriously emotionally disturbed" in order

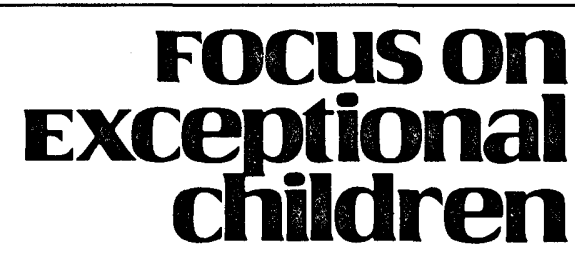

FOCUS ON EXCEPTIONAL CHILDREN (ISSN0015-511X) (USPS 203-360) is published monthly except June, July, and August as a service to teachers, special educators, curriculum specialists, administrators, and those concerned with the special education of exceptional children. This publication is annotated and indexed by the ERIC Clearinghouse on Handicapped and Gifted Children for publication in the monthly Current Index to Journals in Education (CIJE) and the quarterly index, Exceptional Child Education Resources (ECER). It is also available in microform from Xerox University Microfilm, Ann Arbor, MI. Subscription rates: Individuals, $\$ 24$ per year; institutions, $\$ 30$ per year. Copyright - 1987, Love Publishing Company. All rights reserved. Reproduction in whole or part without written permission is prohibited. Printed in the United States of America. Second class postage is paid at Denver, Colorado.

POSTMASTER: Send address changes to:

Love Publishing Company

Executive and Editorial Office

1777 South Bellaire Street

Denver, Colorado 80222

Telephone (303) 757-2579

EDITORIAL BOARD

$$
\begin{gathered}
\text { Edward L. Meyen } \\
\text { University of Kansas } \\
\text { Richard J. Whelan A. Vergason } \\
\text { University of Kansas Medical Center }
\end{gathered}
$$

Stanley F. Love Publisher
Carolyn Acheson Senior Editor for a direct link to be established between the handicapping condition and the misbehavior.

Another U.S. Court of Appeals, in Kaelin v. Grubbs, reinforced the Turlington ruling by affirming that expulsion is a change of placement. This court agreed with the earlier court in taking the position that a handicapped student may be expelled in accordance with due process procedures, but even then a complete cessation of educational services cannot take place. More recently, the ruling in the Turlington case has been affirmed by another U.S. Court of Appeals in the case of School Board of Prince County v. Malone.

Considered in total, these three rulings appear to establish clearly that expulsion of a handicapped student can take place only if the student's misbehavior is not directly related to the handicapping condition, if due process procedures have been properly applied, and if the expulsion does not result in a complete cessation of educational services. In cases wherein the student's misbehavior is determined to be directly linked to his or her handicapping condition, the school is allowed to move the student to an appropriate but more restrictive placement if due process procedures are properly followed in making the placement change.

In Goss v. Lopez the Supreme Court held that "suspension is considered not only to be a necessary tool to maintain order but a valuable educational device." Citing this case, a U.S. District Court, in Board of Education of the City of Peoria, School District 150 v. Illinois State Board of Education ruled that federal law allows suspensions to be used to enforce classroom discipline. The court in this case held that, if the misbehavior of the student is not directly linked to the handicapping condition, a short-term suspension is not a change in placement. But it appears that a determination of the relationship of the student's misbehavior to his or her handicapping condition should be made prior to the suspension. An exception to this appears to be possible under .a ruling by a U.S. District Court in Jackson v. Franklin County School Board. In this case the court held that if a student's behavior is clearly a danger to self or others, immediate removal from the classroom can be justified.

Based on a U.S. District Court ruling, in Mrs. A.J. v. Special School District 1, the due process guidelines established by the U.S. Supreme Court in Goss v. Lopez appear to be sufficient in suspension cases involving handicapped students provided that the suspension does not violate the 10-day rule, including any extensions of the original term of suspension. The court in the Mrs. A.J. case also held that a school system is not required, at the time of suspension, to treat a child as handicapped if that child has not 
yet been ruled as handicapped, even if the child is in the referral process.

In summary, when no direct link seems to exist between a student's misbehavior and the handicapping condition, the courts will allow a handicapped student to be suspended following the same procedures and legal requirements that apply to nonhandicapped students. If there is a direct link between the misbehavior and the handicapping condition, the school may consider moving the student to a more restrictive placement. If this is the action decided upon, it must be done in compliance with due process procedures. Of course, suspension remains as an option even when there is a direct link between the misbehavior and the handicapping condition provided that all parties, including parents, are in agreement.

\section{GUIDELINES FOR EXPULSION AND SUSPENSION}

Expulsion and suspension as disciplinary procedures for handicapped students are used mostly with mildly handicapped students. These procedures are most likely to be considered for students at the middle/junior high and senior high school levels. Disciplinary procedures for younger or severely handicapped students usually are done within the school setting.

Expulsion or suspension of handicapped students may be done under the following conditions:

1. A student may be suspended if his or her behavior poses an immediate danger to self or others. Linkage between the behavior and the handicap is not required prior to suspension but should still be determined as soon afterward as possible.

2. A student may be expelled or suspended if it has been determined that no linkage exists between the misbehavior and the handicap. If the student is expelled, educational services cannot be terminated.

3 . If the student is suspended, the due process requirements in Goss v. Lopez must be followed. And the IEP probably should be reviewed to determine if the new problem indicates a need for a change in the student's IEP.

4. If the student is expelled, the due process requirements in both Goss v. Lopez and P.L. 94-142 should be followed.

5. A student may be suspended if the misbehavior and the handicap are linked, if it and the conditions for its use have been included in the IEP and agreed upon by all parties.

Before considering expulsion or suspension to discipline a handicapped student, the existing policy should be examined to ensure that clearly defined expectations for student behavior are included. Administrators, teachers, students, and parents should be informed of the existing policy. They should know what the rules are, the consequences for violations, and what a student's due process rights are.

The most common method of distributing this information is through a policy handbook. Many school systems do this through separate handbooks for students, parents, teachers, and administrators. Particularly for students and parents, it is a good idea to obtain a signed receipt from them stating that they have received the handbook and had its provisions explained to them. The information also may be distributed to students in the form of a discipline code that is either given to each student or posted in highly visible locations within schools.

The consequences for rule violations should provide a range of options that goes beyond expulsion and suspension. The range of options should accommodate minor infractions as well as serious offenses. The consequences and rules should be systematically related so it is clear what consequence will follow a particular offense. One way to do this is as follows:

1. Develop a set of criteria for what constitutes minor, moderate, and serious offenses.

2. Develop a list of all the problem behaviors that are typically encountered, and classify them according to the criteria.

3. List the disciplinary options, and determine which disciplinary procedures are most appropriate for each category of offense.

This process will result in a reasonable and uniform approach to discipline and can be included in the school system's policy manual. The category criteria also provide a basis for making judgments about new or unusual problem behaviors that may not be on the list.

When a handicapped student has a serious behavior problem, the following questions should be considered:

- What interventions have been used to correct the problem? 
- Have the interventions and their results been clearly documented?

- Could modifications be made in any of the interventions to increase their effectiveness?

- Has a multidisciplinary team examined the records and current behavior to determine if additional academic, psychological, or other evaluations are needed?

- Is there need for an IEP review to consider changing the goals, program, or placement?

- Are behavior goals and management plans included in the IEP?

- Do these plans include the use of expulsion or suspension?

- Would expulsion or suspension harm or benefit the student?

- Has there been a determination of linkage between the misbehavior and the handicap?

- If expulsion or suspension appears to be warranted, have the due process requirements been followed?

Prior to taking any disciplinary action that might involve expulsion or suspension, a group of knowledgeable people should meet and determine if there is linkage between the misbehavior and the handicap. This should be done by a multidisciplinary team (Rosell, 1986) and might include persons usually involved in referral, evaluation, determination of eligibility, and placement of students in special education. The team must determine if the misbehavior and the handicap are linked and if expulsion or suspension is justifiable. Regardless of what disciplinary action is decided on, the student's IEP should be reviewed at the same time, and any indicated revisions made. The group or team may be a system-wide team or an in-school team depending on the circumstances.

One way of determining linkage between behavior and handicap is for the disciplinary team to review a student's records. Behavior rating scales, classroom observations, anecdotal records, social history, psychological reports, and other documentation used in determining eligibility for special education should be scrutinized. Any evidence found in the records for the problem behavior suggests that the behavior and the handicap may be linked.

Another approach is to review the documented characteristics of all students in a particular special education category within the school system. Any problems that appear to be relatively common to students in that category should be considered linked to the handicap.

A third approach is to review the research literature on characteristics of students in a particular category of special education. Behaviors that research indicates are found in a particular category at a significant level in contrast to nonhandicapped students should also be considered as linked to the handicap.

We recently reviewed 30 research studies looking at the behavioral characteristics of students with behavioral disorders (this label is used in its generic sense-i.e., any student meeting the P.L. 94-142 SED definition), learning disabilities, and mild mental retardation. All of these studies will not be referenced in this article, but a few representative studies include Center and Wascom (1986), Center and Wascom (1987), Cullinan and Epstein (1984), Cullinan, Epstein, and Lloyd (1981), Polloway, Epstein, and Cullinan (1985), Polloway, Patton, Epstein, Cullinan, and Luebke (1986), and Sherry (1982).

The handicapped subjects in these studies were special education students who had been placed in special education by whatever criteria their respective states used for determining eligibility. From this review, a list of 161 behaviors was developed. The list was reduced in size by dropping behaviors that appeared to be unlikely to be involved in expulsion or suspension considerations. Further reduction was made by combining behaviors from different studies that appeared to be getting at the same thing. For example, failure to attend, excessive absenteeism, and truancy were all represented by the single term "truancy." This process resulted in a list of 40 behaviors, given in Table 1. The behaviors are cross-indexed to the three categories behavioral disorder, learning disability, and mild mental retardation.

We suggest that the disciplinary team use the first approach described in combination with either the second or third approaches described. No matter how the determination of linkage or lack of linkage is made, a reasonable, consistent, and defensible procedure should be carefully followed.

\section{IN-SCHOOL SUSPENSION}

Another procedure that is becoming more widely used is in-school suspension. To our knowledge, this procedure has not been addressed by the courts relative to either handicapped or nonhandicapped students. In-school suspension, as a disciplinary procedure, is less severe than suspension from school. Therefore, it is reasonable to assume that the guidelines discussed above would be adequate for in-school suspension as well.

In-school suspension has several advantages over suspension that apply to normal and handicapped students alike. First, it avoids the possibility of turning the student loose, unsupervised, in the community. The latter can actually be 
TABLE 1 Behaviors Occurring More Often in Students
with Behavior Disorders, Learning Disabilities
and Mental Retardation

\begin{tabular}{|c|c|c|c|}
\hline Behavior & BD & LD & MR \\
\hline Anxious & $\star$ & & $\star \star$ \\
\hline Attention-seeking & $\star$ & & $\star$ \\
\hline Argumentive & $\star$ & & \\
\hline Boisterous & $\star$ & $\star$ & \\
\hline Critical & $\star$ & $\star$ & \\
\hline Daydreaming & & $\star$ & \\
\hline Deceptive & $\star$ & $\star$ & \\
\hline Defiant & $\star \star$ & & \\
\hline Dependent & & $\star$ & \\
\hline Destructive & $\star$ & & $\star$ \\
\hline Disobedient & $\star$ & & $\star$ \\
\hline Disruptive & $\star$ & $\star$ & $\star$ \\
\hline Enuretic & $\star$ & & $\star$ \\
\hline Fearful & & & $\star$ \\
\hline Fighting & $\star$ & & $\star$ \\
\hline Hot-tempered & $\star$ & & $\star$ \\
\hline Hyperactive & $\star$ & $\star$ & $\star$ \\
\hline Impatient & $\star$ & & \\
\hline Impertinent & $\star$ & & $\star$ \\
\hline Impulsive & & $\star$ & $\star$ \\
\hline Insulting & $\star$ & $\star$ & \\
\hline Irritable & $\star$ & & $\star$ \\
\hline Jealous & & & $\star$ \\
\hline Manipulative & $\star$ & $\star$ & \\
\hline Masturbates & $\star$ & & $\star$ \\
\hline Negative & $\star$ & & $\star$ \\
\hline Obstinant & $\star$ & & $\star$ \\
\hline Provokes others & $\star$ & $\star$ & $\star$ \\
\hline Restless & $\star$ & $\star$ & $\star$ \\
\hline Show-off & $\star$ & & $\star$ \\
\hline Shy & $\star$ & & $\star$ \\
\hline Socially inept & $\star$ & $\star$ & $\star$ \\
\hline Steals & & & $\star$ \\
\hline Suggestible & & & $\star$ \\
\hline Tantrums & $\star$ & & $\star$ \\
\hline Threatens & $\star$ & $\star$ & \\
\hline Truant & $\star$ & & $\star$ \\
\hline Uncommunicative & $\star$ & $\star$ & \\
\hline Uncooperative & $\star$ & & $\star$ \\
\hline Withdrawn & & & $\star$ \\
\hline
\end{tabular}

$\mathrm{BD}=$ behavior disordered

$\mathrm{LD}=$ learning disabled

$\mathrm{MR}=$ mentally retarded a rewarding experience for some students and may aggravate the misbehavior at school, to get suspended again. Second, it segregates the student from the general school population, which reduces the potential for disruption and may be viewed as undesirable (punitive) by the student. Finally, in-school suspension with an appropriate educational program can give students a meaningful learning experience, which can be designed to benefit the student both academically and behaviorally.

The in-school suspension program appears to be a viable alternative to suspension and expulsion for both handicapped and nonhandicapped students. If the in-school suspension period does not exceed the 10-day rule and, in the case of handicapped students, the misbehavior is not directly related to the student's handicapping condition, there appears to be no legal barrier to placing students in an in-school suspension program for disciplinary purposes.

Based on the previous discussion of court cases, placement of a handicapped student in an in-school suspension program should not be considered a change in placement. Even if the student has to be transported to another site, that is no reason to view this as a change of placement. And there is no reason to believe that in-school suspension would require modification of a handicapped student's IEP.

In Board of Education of the City of Peoria, School District 150 v. Illinois State Board of Education, a U.S. District Court ruled that a short-term suspension was not a change in placement. Because short-term suspension appears not to be considered a change in placement, a modification of the IEP is not necessary. There is no reason to believe in-school suspension would be judged any differently. Any time a handicapped student is suspended from special education for disciplinary reasons, however, a review of the student's IEP should be undertaken.

In-school suspension should be a more attractive and defensible disciplinary procedure to parents and the general public alike, particularly when it is designed as an educational program and not as just a detention program. Some of the considerations that should be made when setting up an in-school suspension program are discussed in the remainder of this article, under the three areas of operating policy, curriculum, and management of the program.

\section{Policy Considerations}

To have a successful program, a set of operating policies, consistent with the purpose of the program, must be developed. The following general policies are suggested: 
1. The age range among students in the program should be no more than three grades or three years. This might require two programs, one at the middle/junior high school level and one at the senior high school level. Alternatively, a single program could operate on a split session, half-day basis.

2. A maximum enrollment should be set. The suggested level is 15 students. Students in an in-school suspension program are there, of course, because of inappropriate behavior of a relatively serious nature. If a teacher is going to be able to maintain adequate discipline and supervision and at the same time conduct a meaningful education program, the number of students has to be relatively small. Fifteen students should, in most cases, be a manageable number, and not prohibitively expensive.

3. Specific criteria should be set for assigning a student to the program. Whatever the criteria used, they should ensure uniform treatment of all students being considered for in-school suspension. In particular, criteria should be related to the seriousness of the student's offense. For example, Level Two offenses might consist of behaviors classified as moderate offenses; Level Three offenses might be behaviors classified as serious offenses. The criteria also should cover the duration of the placement and be systematically related to the seriousness of the offense. For example, a Level Two offense might warrant 3 days, and a Level Three offense might warrant 5 days of in-school suspension.

4. Regardless of the intervals used, all placements should be for fixed periods that are preset and uniform.

5. Placement in the program should have a consistent begining point-e.g., Monday or Wednesday.

6. Return to the student's regular program should be contingent on successful participation in the program, with specific criteria for what constitutes successful participation. These criteria should cover not only the current placement in the in-school suspension program but also the number of placements within a school year. Multiple placements within a school year suggest that the in-school suspension program is not having the intended effect and is not a successful disciplinary procedure for the student.

7. Failure to meet the participation criteria successfully should result in a hearing to consider other options such as suspension from school, a change in placement to a more restrictive environment, or expulsion.

8. For any student placed in the in-school suspension program, successful participation should be a criterion for acceptance in other school programs-e.g., alternative program, athletic program.

\section{Curriculum Considerations}

Any brief-duration placement such as in-school suspension, with a heterogeneous group of students relative to age, grade, and ability, will have logistic and coordination problems. Obtaining academic assignments and materials from many different teachers, with different curricula, different schedules, and possibly in different schools, can represent a major obstacle to a successful program. Further, finding a teacher/supervisor for an in-school suspension program who can adequately address all the instructional needs represented in a heterogeneous class is difficult. A teacher might have both regular and mildly handicapped students, in a variety of curricula and at different levels within a given curriculum. Thus, the teacher may be responsible for math, science, language arts, social studies, and adaptation of these subjects for handicapped students.

Teachers in in-school suspension programs also need to have good behavior management skills. Few teacher training programs for regular education teachers provide sufficient training in these skills. Because in-school suspension is most frequently used with students at the secondary level, finding a teacher/supervisor can be a major challenge because of the increasing subject specialization at the secondary level. This will be particularly troublesome for small programs. if the program serves a large school system and has enough classes to permit departmentalization, it may not be as difficult as for a small program with only one or a few classes.

Two approaches can be taken with curriculum. First, the in-school suspension program can use each student's regular curriculum. The difficulties related to this option, just discussed, include logistics and finding qualified teachers. The logistics problems can be somewhat reduced if the in-school suspension program has on hand a complete set of curriculum materials, in adequate quantity, for all subject areas and grade levels for the population served. Then, the appropriate assignments would be obtained from the originating school and teachers, with sufficient lead time to permit adequate planning time for the in-school suspension teacher(s).

The only satisfactory way to find qualified teachers is to have a program large enough to allow departmentalization. Even with departmentalization, care must be taken to select teachers who have good behavior management skills. If these teachers are in short supply-which is likely-they should receive training in behavior management, either through inservice programs or coursework. Most special 
education teacher training programs offer courses of this nature. These courses could be used, or the personnel who teach them could be a resource for inservice training. Preparation for behavior management responsibilities should be a condition for employment, which should be met prior to assignment to teaching responsibilities.

An alternative to keeping students in their regular curriculum is a stand-alone curriculum. This would allow uniformity in programming; it permits the in-school suspension teacher to maintain a consistent approach to both curriculum content and instruction. This solves the logistics problem and also reduces the need to have teachers who are qualified to teach the curriculum, because the range of content that would have to be taught is limited. In addition, the topics to be taught in such a curriculum can be limited to areas that many teachers should be able to teach or be prepared to teach in a reasonable amount of time. This approach does not solve the need for behavior managment skills, but that need can be handled by training, as discussed previously. Two possible curricula are either a generic learning skills curriculum or a functional academic curriculum.

The learning skills program attempts to teach the student generic learning strategies that can be applied in any subject area (Alley \& Deshler, 1979). These are skills that aid learning in any subject area and thus are not content-bound. Suggested components might include (Center, in press):

\section{Listening skills}
a. Listening for organizing cues
b. Listening for emphasis cues
c. Listening for main and supporting ideas
d. Questioning for clarification

2. Reading skills
a. Using a table of contents
b. Using an index
c. Using a glossary
d. Using topic headings
e. Using skimming
f. Using scanning
g. Using intensive reading

3. Study skills
a. Developing study questions
b. Note-taking skills
c. Outlining skills
d. Reference skills
e. Study techniques (e.g., SQ3R method)
f. Preparing for tests (e.g., SCORER method)

4. Time management
a. Setting goals
b. Setting priorities
c. Estimating time
d. Planning a schedule

The functional academics program attempts to teach a student to apply basic academic skills to problems in daily living and, in particular, the world of work (Kokaska \& Brolin, 1985; Wircenski, 1982). The curriculum might include components similar to the following:

\section{Paying bills}

2. Opening and using a checking account

3. Budgeting

4. Applying for and using credit

5. Buying and maintaining a car

6. Using public transportation

7. Job finding resources

8. How to get information about prospective employers

9. Applying for a job

10. Interviewing for a job

11. Employee/employer relations

12. Job retention

A stand-alone curriculum such as this one has several advantages. First, all necessary teaching materials can be on hand and do not have to be collected for each student individually. Second, teachers would not have to have specialized preparation, to the extent subject-area teachers must, to teach the curriculum. Third, the teacher has control of the curriculum and can plan and teach within a predictable framework. Fourth, the above curricula are not hierarchical and can be entered and exited at almost any time. Fifth, the curriculum is general enough to be suitable for a variety of students.

Many objections might be raised about the use of such a curriculum. In the first place, the objectives that would be associated with the curriculum would not be on a student's IEP. Because a student can be suspended without revising the IEP, a less intrusive intervention such as in-school suspension wouldn't likely require a revision of a student's IEP. Nor would brief and temporary instructional services, provided as an alternative to a temporary suspension of services altogether, have to conform to a student's IEP. The IEP issue could be laid entirely to rest if administrators were to follow the suggestions in the above guidelines and write in-school suspension and its curriculum into a student's IEP to begin with.

Another potential objection is that the stand-alone curriculum would not be appropriate for, and meet the needs 
of, mildly handicapped students. But it is clearly more appropriate than a complete but temporary suspension of services. Further, we have never encountered a mildly handicapped student-or, for that matter, many regular, secondarylevel, or even college-level students-who would not benefit from a course in general learning strategies or even the functional application of academic skills.

Still another possible objection is that putting the student into an alternative curriculum will not contribute toward the ongoing instruction in the regular placement. Again, temporary suspension of educational services will not contribute to a student's keeping up either. Certainly, acquiring some useful skills during in-school suspension is preferable to several days of lost time that suspension from school would entail. In addition, a student's regular teacher(s) could be required to provide parents with a list of homework assignments during the suspension period, to help the student keep up. This is probably more important for mainstreamed classes than for special education classes. Instruction in the latter should be individualized, and the special education teacher should be able to accommodate a student's absence more readily than would a regular class teacher who relies on group instruction. Of course, we are talking about a few days here, not an extended period of time. Many students are out of school for similar periods because of illness or family situations.

Finally, what if a student is sent to in-school suspension several times and the curriculum becomes repetitious and boring? A curriculum such as one of those suggested here cannot be taught in its entirety in a few days or even a few weeks. Rarely would a repeater enter at exactly the same point in the curriculum that it was last entered. And even if that were to occur, the odds are that a student would not have completely mastered the skills the last time through. Of course, if objectives related to the stand-alone curriculum are already in the student's IEP, instruction in the in-school suspension program can be individualized to maintain some continuity with the special education program. A student should not repeat in-school suspension more than a few times during a school year. Earlier we suggested that the effect of in-school suspension on each student be evaluated. If the intervention does not appear to be having the desired effect, other disciplinary options should be investigated for that student.

A final curriculum consideration is related to behavior. An in-school suspension program should have a deportment component regardless of the approach taken to the academic curriculum. This is important because students are usually in the program because of their inappropriate behavior. If the program is to be beneficial, it must address student behavior. This component is also important for determining if a student has had a successful experience in the program. The deportment component should emphasize behaviors that aid good classroom functioning (Adelman, 1982). The following components represent the kinds of behaviors that promote positive attitudes in teachers toward students:

1. Being on time

2. Having necessary materials

3. Completing assignments on time

4. Responding to questions appropriately

5. Following directions appropriately

6. Keeping materials and personal belongings neat and orderly

7. Maintaining appropriate sitting behavior (e.g., good posture)

8. Remaining seated unless given permission to get up

9. Getting permission before speaking

10. Being courteous to others.

\section{Management Considerations}

The management component should provide a systematic approach to monitoring students and giving them feedback on their performance in the program. The teacher also might want to provide a student's parents with performance feedback. The management component also would aid teacher record keeping and supply evaluation data.

One way to manage the program would be to use a point system. For illustration, we will briefly describe one of these. A point in this system is called a performance unit (PU). PUs are awarded to students on a predetermined basis, for specific behaviors or levels of achievement. PUs are deducted for failure to meet requirements in the deportment program. These fines are also fixed according to a predetermined schedule. The system should be explained to students on entry into the program so they know how it works. Table 2 is a suggested PU schedule.

The PUs used in the program must be backed up by various rewards that have incentive value to the students. What these should be varies according to the students. Probably the best approach is to use a menu of rewards that encompasses enough variety for most students. A few examples are: extra lunch or dessert, free time to read magazines of listen to music, social time to talk or play a game, and purchase of in-school suspension time (i.e., reduction of the placement period).

A more detailed description of a point-based management system has been offered by Center and Arnault (1985). In 
TABLE 2

\section{A Suggested Schedule for Awarding Performance Units (PUs) to Students}

\section{Attendance}

PUs

a. Present and on time

30

b. Present and no more than 10 minutes tardy

c. Present and over 10 minutes tardy

d. Excused absence (does not count toward days assigned to program)

e. Unexcused absence (does not count toward days assigned to program, and more than one such absence initiates an expulsion hearing)

\section{Deportment}

Per period

Each infraction of any of the standards in the deportment program

\section{Instruction}

a. Per class period

b. For completing task(s)

c. For task accuracy (criterion is $90 \%-100 \%$ on single task, or average on multiple tasks within a class period)

d. Same criterion except $80 \%-89 \%$ accuracy 30

e. Same criterion except $70 \%-79 \%$ accuracy 20

f. Same criterion except $60 \%-69 \%$ accuracy 10

g. Accuracy of $59 \%$ or less (10 PUs still possible if task(s) completed)

this system, each student has an individual record sheet covering program components. Both the academic and deportment curriculum are represented on the record sheet, as shown in Figure 1. Academic and deportment PUs are awarded at the end of each class period. Fines can be levied at any time. The data on the record sheet are used to evaluate a student's daily performance. Accumulated data sheets over the course of the placement period are used to evaluate the overall performance. Predetermined criteria are set for the minimal level of performance required for successful participation. Figure 1 is only an example for illustration. It can be easily modified for a particular situation.

\section{CONCLUSION}

This article does not cover every possible consideration in using in-school suspension. We have merely raised some of the major issues and offered a few suggestions. Obviously, this discussion cannot address the specific needs of an individual school system. But the points covered, suggestions, and examples will serve as a useful guide to anyone concerned with disciplinary removal of students from special education or regular education.

\section{REFERENCES}

Adelman, M. (1982). School survival skills: A guide for teachers. Media, PA: Delaware County Public Schools.

Alley, G., \& Deshler, D. (1979). Teaching the learning disabled adolescent: Strategies and methods. Denver: Love Publishing.

Center, D. (In press). Curriculum and teaching strategies for students with behavioral disorders. Englewood Cliffs, NJ: Prentice-Hall.

Center, D., \& Arnault, L. (1985). Establishing and balancing a classroom management system. Exceptional Child Education Resources, 16(4), 459. (ERIC Document Reproduction Service No. ED 245 487).

Center, D., \& Wascom, A. (1986). Teacher perceptions of social behavior in learning disabled and socially normal children and youth. Journal of Learning Disabilities, 19, 420-425.

Center, D., \& Wascom, A. (1987). Teacher perceptions of social behavior in behaviorally disordered and socially normal children and youth. $B e$ havioral Disorders, 12, 200-206.

Cullinan, D., \& Epstein, M. (1984). Patterns of maladjustment of behaviorally disordered male students. Behavioral Disorders, 9, 175-181.

Cullinan, D., Epstein, M., \& Lloyd, J. (1981). School behavior problems of learning disabled and normal girls and boys. Learning Disability Quarterly, 4, 163-169.

Kauffman, J., Cullinan, D., \& Epstein, M. (1987). Characteristics of students placed in special programs for the seriously emotionally disturbed. Behavioral Disorders, 12, 175-183.

Kokaska, C., \& Brolin, D. (1985). Career education for handicapped individuals (2nd ed.). Columbus, OH: Charles E. Merrill.

Polloway, E., Epstein, M., \& Cullinan, D. (1985). Prevalence of behavior problems among educable mentally retarded students. Education \& Training of the Mentally Retarded, 20, 3-13.

Polloway, E., Patton, J., Epstein, M., Cullinan, D., \& Luebke, J. (1986). Demographic, social, and behavioral characteristics of students with educable mental retardation. Education \& Training of the Mentally Retarded, 2I, 27-33.

Rosell, J. (1986). An analysis of school district policies for disciplinary action with handicapped students. Unpublished paper, University of Nebraska-Lincoln, Dept. of Special Education.

Sherry, L. (1982). Non-task oriented behaviors of educable mentally retarded, emotionally handicapped, and learning disabled students. Educational Research Quarterly, 4, 19-29.

Wircenski, J. (1982). Employability skills for special needs learners: An integrated program of reading, math, and daily living skills. Rockville, MD: Aspen Systems.

\section{SUGGESTED READINGS ON LITIGATION}

Data Research, Inc. (1986). Handicapped students and special education (3rd ed.). Rosemont, MN: Author.

Slenkovich, J. (1984). Understanding special education law (Vol. 1). Cupertino, CA: Kinghorn Press.

Turnbull, H. R. (1986). Free appropriate public education: The law and children with disabilities. Denver: Love Publishing.

Turnbull, H., \& Fiedler, C. (1984). Judicial interpretation of the Education for All Handicapped Children Act. Reston, VA: Eric Clearing House on Handicapped and Gifted Children. 


\section{Performance Unit (PU) Record Sheet}

Name:

Beginning Date:

\begin{tabular}{|c|c|c|c|c|c|c|c|}
\hline & & Monday & Tuesday & Wednesday & Thursday & Friday & Total \\
\hline \multicolumn{8}{|l|}{$\begin{array}{l}\text { Attendance } \\
\text { 7:50-8:00 }\end{array}$} \\
\hline \multirow{2}{*}{$\begin{array}{l}\text { Period 1 } \\
\text { 8:00-8:50 }\end{array}$} & Deport. & & & & & & \\
\hline & Instr. & & & & & & \\
\hline \multirow{2}{*}{$\begin{array}{l}\text { Period } 2 \\
\text { 9:00-9:50 }\end{array}$} & Deport. & & & & & & \\
\hline & Instr. & & & & & & \\
\hline \multirow{2}{*}{$\begin{array}{l}\text { Period } 3 \\
\text { 10:00-10:50 }\end{array}$} & Deport. & & & & & & \\
\hline & Instr. & & & & & & \\
\hline \multirow{2}{*}{$\begin{array}{l}\text { Period } 4 \\
\text { 11:00-11:50 } \\
\end{array}$} & Deport. & & & & & & \\
\hline & Instr. & & & & & & \\
\hline $\begin{array}{l}\text { Clean-Up } \\
\text { Lunch } \\
\text { 12:00-12:50 }\end{array}$ & Deport. & & & & & & \\
\hline \multirow{2}{*}{$\begin{array}{l}\text { Period } 5 \\
1: 00-1: 50\end{array}$} & Deport. & & & & & & \\
\hline & Instr. & & & & & & \\
\hline $\begin{array}{l}\text { Free Time } \\
2: 00-2: 40\end{array}$ & Deport. & & & & & & \\
\hline \multicolumn{8}{|c|}{ Cumulative Total } \\
\hline
\end{tabular}

\begin{tabular}{|l|l|l|l|}
\cline { 2 - 4 } \multicolumn{1}{c|}{} & Earned & Possible & Percent \\
\hline Monday & & & \\
\hline Tuesday & & & \\
\hline Wednesday & & & \\
\hline Thursday & & & \\
\hline Friday & & & \\
\hline Total & & & \\
\hline
\end{tabular}

Minimum Success Criteria:

1. Daily, $70 \%$ of possible PUs.

2. Weekly, $70 \%$ of possible PUs.

3. Placement period, $70 \%$ of possible PUs.

FIGURE 1

Example of a Record-Keeping Form for an In-School Suspension, Management Program 


\title{
Effective Teaching for Mildly Handicapped Learners
}

\author{
Connie Campbell and Beverly Clevenger
}

As mainstreaming has become commonplace in classrooms, teachers often call us at The Learning Exchange to ask about classes or study groups focusing on special education strategies. They are concerned about their need to have certain technical and exceptional skills to reach mildly handicapped children in regular classes. They are often surprised that we don't believe they require "special" skills but that they need instead to finely hone effective teaching skills that work with all students.

This conclusion grows out of our work with over 14,000 teachers, principals, and administrators in more than 70 districts in the Kansas City area. After 15 years of experience with urban, suburban, and rural districts, we believe that most competent teachers already know, and use to some extent, the teaching skills that are most useful in teaching mainstreamed, mildly handicapped learners. But teachers often $d o$ lack the experience and practice to apply these skills on a broader basis. If they are to successfully reach the wider diversity of abilities they now face in mainstreamed classes, they have to more effectively diagnose, monitor, and adjust their instruction.

When teachers diagnose student needs and monitor and adjust their teaching strategies, they are applying a decisionmaking model of instruction. Extending and expanding the following components of this teaching model help teachers understand how they can better meet the instructional needs of all students.

\section{AWARENESS OF STUDENT NEEDS}

One of the most important aspects of teaching any lesson is the analysis that precedes it. This analysis should focus on what is to be learned, who will learn it, and the teacher's role. This analysis of content, process, and behavior is particularly crucial with mainstreamed mildly handicapped students because research shows that teachers often apply differing standards, expectations, and attention to marginal learners that decrease their opportunities for success in traditional classroom settings.

Good and Weinstein (1986) have documented that children perceived to be more capable tend to be given more opportunities for meaningful tasks, more learning autonomy,

\footnotetext{
The authors are associated with The Learning Exchange, Kansas City, Missouri, where Connie Campbell is Executive Director and Beverly Clevenger is Assistant Director of Teaching Programs. The Learning Exchange is a not-for-profit educational resource center providing innovative programs, consulting, materials, training, networking, and other support for improving the quality of instruction.
}

and more time to do their work than are less capable and low-achieving pupils. These higher achievers are more likely to get accurate feedback about their errors, more respect for their judgments, and more teacher response to their needs and interests. Brophy and Good's (1969) review of the research shows that teachers tend to stay with their high-expectation students after they fail to answer an initial question, and often extend the interaction with cues and other questions. In contrast, teachers often move away from students for whom they have low expectations by giving them the correct answers for wrong answers or calling on someone else.

Additionally, more capable, higher achieving students are likely to be systematic, analytical thinkers who can work alone at abstract tasks. Mildly handicapped children are more likely to require cues, prompts, and modeling to solve problems, and they will need to be explicitly taught how to recognize the basic concepts and large organizational patterns of an academic subject.

Through awareness of these differences, teachers can anticipate and more effectively apply strategies to reach all levels of students during the lesson. When teachers have a clear understanding of what is to be learned, they are more able to analyze the tasks each student must accomplish. In addition, teachers must identify their own behaviors, as well as those of the students, that will most enhance mastery of the objective.

\section{MONITORING LEARNING AND ADJUSTING INSTRUCTION}

Teachers who monitor learning on an ongoing basis during their lesson increase the probability that students will learn more effectively. Important aspects of monitoring include modeling and coaching, supervised practice with meaningful exercises, and a variety of total-class and small-group approaches.

One of the most exciting outcomes from monitoring of instruction is the active participation it requires from students. Teachers have planned for specific outcomes, and if the students' behaviors do not indicate that those outcomes are being achieved, the teacher can immediately adjust and modify instruction to increase learning success.

In the role as model and coach, the teacher can draw upon many ways to deliver instruction and monitor progress for success in the classroom. For example, group-based mastery learning programs consistently produce positive gains (Guskey \& Gates, 1986), and peer-tutoring and 


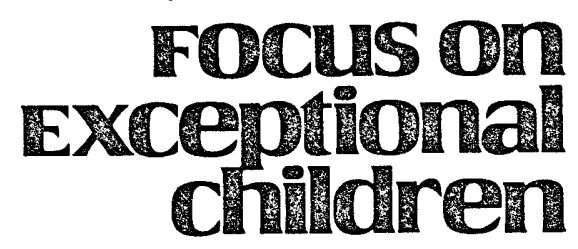

cooperative-team learning help individualize instruction (Slavin, 1985). These strategies also increase "reciprocal learning" (Palincsar \& Brown, 1985), which results when students cooperate on a task. No one way of teaching and grouping meets all student needs or addresses the learning styles and modalities that favor every child. Therefore, although monitoring is important in any classroom, it is essential for classes with mainstreamed, mildly handicapped youngsters.

\section{PRINCIPLES OF LEARNING}

Many experienced teachers intuitively teach, based on principles of learning. What they lack is the common vocabulary for these principles. Without the labels and knowledge of how these principles influence student learning, teachers will have difficulty making conscious decisions about the options they have for facilitating students' motivation to learn, rate and degree of learning, and retention and transfer of learning (Rehberg, 1984).

For example, research on motivation shows that lowachieving students need to experience success $95 \%$ to $99 \%$ of the time to remain motivated for learning. Knowing this and other principles of learning helps teachers to develop successful experiences for the mildly handicapped student as well as other students in their classrooms.

\section{PEER COACHING}

Many times we have found that teachers have difficulty analyzing and adjusting their instruction on their own. They need feedback from peers and supportive supervisors who will help them identify and label learning situations and appropriate teaching strategies. In particular, teachers with widely heterogeneous classes gain from a working environment that emphasizes ideas, interaction, and shared professional responsibility. Otherwise, their isolation may contrib- ute to their feelings as "victims" of externally imposed rules and government regulations rather than as "committed participants in the process of learning" (Howe \& Edelman, 1985). Peer coaching is a tool that helps teachers with mainstreamed students succeed in an atmosphere of support and instructional growth.

In summary, we have found that when teachers initiate a decision-making model for instruction, they are able to extend and expand their skills, capabilities, and options for instructing all children who may be assigned to their classrooms. By diagnosing student needs, monitoring learning, and adjusting instruction based on principles of learning, with the help of their associates, teachers can manage the challenge of mainstreaming in ways that can increase learning for all students.

\section{REFERENCES}

Brophy, J., \& Good, T. (1969). Teachers' communication of differential expectations for children's classroom performance: Some behavioral data (Report Series No. 25). Austin, TX: University of Texas, Research and Development Center for Teacher Education.

Good, T., \& Weinstein, R. (1986). Teacher expectations: A framework for exploring classrooms. Improving teaching: 1986 ASCD yearbook (pp. 63-85). Alexandria, VA: Association for Supervision and Curriculum Development.

Guskey, T., \& Gates, S. (1986, May). Synthesis of research on mastery learning in elementary and secondary classrooms. Educational Leadership, 43, 73-79.

Howe, H., \& Edelman, M. (1985). Barriers to excellence: Our children at risk (pp. 38-39). Boston: National Coalition for Advocates of Students.

Palincsar, A., \& Brown, A. (1985). Reciprocal teaching: Activities to promote "reading with your mind." In T. Harris \& E. Cooper (Eds.), Reading, thinking, and concept development (pp. 147-159). New York: College Entrance Examination Board.

Rehberg, P. (1984, Spring). Model fits any situation. Nebraska School Leader, 8-11.

Slavin, R. (1985). Team-assisted individualization: A cooperative learning solution for adaptive instruction in mathematics. In $\mathrm{M}$. Wang \& $\mathrm{H}$. Walberg (Eds.), Adapting instruction to individual differences (pp. 236253). Berkeley, CA: McCutchan Publishing Corp.

\section{Professional update}

\section{NEW BOOK}

\section{Severe Behavior Disorders \\ Of Children and Youth}

Edited by Robert B. Rutherford, Jr., C. Michael Nelson, Steven R. Forness

This new book contains selected presentations from the Ninth Annual Conference of Teacher Educators for Children with Behavioral Disorders (held in Scottsdale, Arizona, November, 1985). The topics deal with behavior disorders, teacher training, parent training, and interventions.

New areas of research and application include metaanalysis, reevaluation of testing and classifying procedures, sociometric training methods, productive involvement of the family, and more. This collection represents the more recent thinking in the area of behavioral disturbance and will be of interest to anyone involved with severely troubled youngsters.

The publisher of this 200-page paperback is College-Hill Press, San Diego. 